\title{
DIE BETEKENIS VAN DIE SELFSTANDIGWORDING VAN DIE P.U.K. VIR C.H.O.
}

(Toespraak van dr. A. J. R. van Rhyn, vise-kanselier van die Universiteit van S.A. tydens die promosieplegtigheid van P.U.K. op 16 Maart 1951).

Laat my eers toe om met $u$ van harte te simpatiseer met die heengaan van ons almal se geliefde en hoog geëerde prof. Postma. P.U.K. het met sy afsterwe 'n groot opvoedkundige en 'n wyse raadgewer verloor. SuidAfrika sal sy nagedagtenis bly eer vir wat hy vir sy volk op onderwysgebied gedoen het.

Terselfdertyd wil ek u gelukwens met die benoeming van prof. Joon van Rooy as sy opvolger. As ek sê dat die Raad geen beter keuse kon gemaak het nie, dan het ek genoeg gesê.

Dit is vir my aangenaam om al die studente wat by hierdie geleentheid hul grade ontvang van harte geluk te wens met die hoë onderskejding wat hulle te beurt val.

Ons wens hulle alle sukses toe vir die toekoms, en die wens is dat hulle so gebruik sal maak van die kennis en ervaring wat hulle op P.U.K. opgedoen het dat die gemeenskap van die omgewing waarin hulle hul gaan vestig 'n agting sal koester vir 'n akademiese opleiding en daarby sal besef dat die opofferings wat die volk hom terwille van hoër onderwys getroos, wel die moeite werd is.

By geleentheid van hierdie laaste gradeplegtigheid van die Universiteit van Suid-Afrika wat gehou word onder die beskerming van die P.U.K. vir C.H.O. wil ek graag iets sê oor die betekenis van die selfstandigwording van hierdie inrigting. Die werklike betekenis van dic gebeurtenis is vir my nie daarin geleë dat Potchefstroom nou 'n selfstandige universiteit verkry nie. Ongetwyfeld is hierdie gebeurtenis van die aller-grootste belang vir hierdie dorp met sy lang en waardige geskiedenis as opvoedingsentrum. Maar, geleë in die nabyheid van twee groter univer- 
siteitstède sou Potchefstroom ook wel sonder 'n universiteit, met enige ongerief, maar sonder wesenlike opvoedkundige skade, kon klaarkom. En wat hier van Potchefstroom gesê is geld ook vir Transvaal en vir die hele Suid-Afrika. Daar sou selfs 'n saak uitgemaak kon word vir die vermindering, eerder as die vermeerdering van ons aantal selfstandige universiteite. En tog sou, volgens my beskouing, die land opvoedkundig oneindig armer gewees het sonder die Potchefstroomse Universiteit vir Christelike Hoër Onderwys. Want die betekenis van die gebeurtenis wat gevier word lê nie in die selfstandigwording van die P.U. nie, maar van die P.U. vir C.H.o.

Daar is diegene wat die mening toegedaan is dat universiteite alle lewensrigtings moet omvat en nie die studente so moet vorm dat hulle een bepaalde lewensbeskouing sal toegedaan wees nie. Dit mag so wees in die ouere lande wat reeds op vaste bodem staan. In 'n jong land egter soos Suid-Afrika beskou ek dit uiters wenslik dat ons universiteite hulle daarop sal toclê om daardie lewensrigting aan hul studente aan te wys wat die voorouers gevolg het, en daardie ideologieë sal bly propageer wat tot so'n mate 'n bron van krag en besieling vir die stoere baanbrekers was dat hulle te midde van die grootste gevare en moeilikhede die lig van die Christelike beskawing tot in die donkerste dele kon indra.

Laat my toe om hierdie stelling kortliks nader te verduidelik .Die moderne universiteite gaan byna sonder uitsondering uit van wat ek sou wil noem dic gedagte van absolute leervryheid. Daarmee bedoel ek die vryheid van én dosente én studente om die feite van die natuur en van die menslike lewe deur ondersoek bloot te lê en te vertolk sonder die bindende inwerking van vooropgestelde beginsels of aanvaarde waarhede wat nie deur kritiese ondersoek as bewese aanvaar word nie. As daar dan gewys word op die talryke mistastinge van die menslike rede, op die hipoteses, eenmaal aangeneem as bewese waarhede, wat maar weer moes plek maak vir ander en nuwer teorieë, dan word daarop gewys dat juis langs hierdie weg van "trial and error" die wetenskap op die duur die beste gedien word, en dat dit bewys word deur die enorme vooruitgang van wetenskap en tegnick. So word dan die hoop gekoester dat die menslike rede, bevry van alle bande van vooroordeel en vooropgestelde beginsels, nog daarin mag slaag om die geheime nie alleen van ons aardbol nie maar ook van die lewe self en van die heelal bloot te lê.

Die tyd ontbreek my om hierdie gedagtegang hier verder te bespreek en ek bepaal my daarby om in alle beskeidenheid die standpunt van die draers en ondersteuners van die P.U. vir C.H.O. kortliks te probeer stel.

Die uitgangspunt hier is dan dat die geopenbaarde Christelike grondbeginsels óf waar of onwaar moet wees. Indien die Christendom 
opgevat word as slegs 'n "way of life," 'n reeks rigsnoere vir die sedelike lewe, nou ja, dan val daar oor die saak verder nie te redeneer nie. Vir die belydende Christen bestaan daar egter geen twyfel dat die in die Bybel geopenbaarde dinge ewige en bindende waarhede is nie. Hy weet dat die Bybel geen wetenskaplike handboek is nie, nie geskrywe is in wetenskaplike taal nie maar bedoel is om, bevatlik vir mense van alle tye, die heilswaarhede te openbaar. Maar hy weet ook dat die genoemde grondbeginsels of absoluut waar of onwaar moet wees en dat indien hulle waar is, soos hy in die geloof aanneem, hulle ook vir die wetenskap bindend moet wees. Daarom kan van 'n Christelike wetenskap gepraat word, 'n wetenskap wat vry is, nee selfs die opdrag het, om binne die grense aan hom gestel, die feite van die skepping, beide van die natuur en van die menslike lewe, bloot te lê en te vertolk.

In hierdie, deur die Christelike gewete aan hom opgelegde roeping, lê die betekenis van die selfstandigwording van die P.U. vir C.H.O. Daarmee is ' $n$ lang gekoesterde ideaal bereik, en het die strewe van die inrigting, waaraan met soveel toewyding gearbei is, sy wetlike erkenning verkry. Want nou vir die eerste maal staan daar duidelik in sy wet geskrywe dat die Raad die plig het om by die benoeming van die doserende, navorsende en administratiewe personeel toe te sien dat die christelik-historiese karakter van die universiteit gehandhaaf sal word. Nie 'n kerkistiese, maar 'n christelike universiteit, dit is die doel en dit is die taak wat hom opgelê is. Hier is dus 'n inrigting waarin Christene van verskillende kerke kan saamwerk as Christene om die wetenskap te beoefen in die lig van die ewige Christelike waarhede.

Dit lê op die skouers van die universiteit 'n grootse, maar terselfdertyd moeilike en verantwoordelike taak, die taak om 'n Christelike wetenskap uit te bou, te bewaar, uit te dra in die volksgemeenskap, en eindelik om jong manne en vroue op te lei vir hulle lewenstaak, nie alleen akademies gelykwaardig toegerus nie, maar daarby kragtig in beginselbelewing, vervul met die drang om die geheime van die skepping bloot te lê, vry voor alle mense ook in hulle intellektuele lewe.

On dié doel te bereik is daar in die eerste plek die taak om by benoeminge steeds toe te sien dat manne en vroue verkry word, wat nie alleen die grondbeginsels van die inrigting bely nie, maar wat ook voldoen aan die hoogste akademiese eise. 'n Moeilike taak, want goeie belydende Christene, akademies slegs middelmatig toegerus, kan die groot taak in diskrediet bring, en akademies voortreflik toegeruste mense sonder portuigde beginselbelewing, ook in die wetenskapsbeoefening, moet dir nagestreefde doel gewis verydel.

Vir die personeel stel die beginsels van die inrigting die taak van naarstige en volgehoue arbeid. Christelike wetenskap mag geen dek- 
mantel wees vir intellektuele luiheid nie; inteendeel-dit vereis: ernstige ondersoek, ernstige navorsing, meermale langs nog onbetrede weë om 'n wetenskap op te bou wat wortel in die godsdiens van die vaders. Dit sal in baie gevalle ' $n$ eensame arbeid wees, sonder die hulp en wegwysers wat vir die navorser in baie ander inrigtings tot sy beskikking staan. Dit sal in menige opsig baanbrekerswerk wees wat hoog moet staan om die aandag te trek buite die inrigting, ja buite Suid-Afrika self, om sodoende die werk van die inrigting uit te kan dra en vrugbaar te kan maak vir die volksgemeenskap.

Die stigting en uitbouing van die inrigting was op sigself 'n geloofsdaad. Mag hierdie geloofskrag ook in die toekoms sy volle werking openbaar en die P.U. vir C.H.O. van $\mathrm{krag}$ tot $\mathrm{krag}$ voer.

Die oë van Christelike Suid-Afrika sal op u gevestig bly in hoë verwagting; strenge eise sal aan u gestel word. Mag u die geloofskrag behou om in u taak na die hoogste hoogte te mik, dit met getrouheid te vervul nie alleen in die belang van die wetenskap nie maar ook in belang van ons land met sy menigvuldige probleme en van ons volk wat nog ' $n$ lang stryd sal moet voer vir die verwesenliking van sy ideale. 